ANNALS, AAPSS, 581, May 2002

\title{
Globalization and Culture: Placing Ireland
}

\author{
By G. HONOR FAGAN
}

ABSTRACT: Instead of asking how globalization can help us understand Ireland today, this article starts from the premise that Ireland may be useful for an understanding of globalization. Always at a crossroads culturally and through its huge migration overseas, contemporary Ireland is seen as the epitome of a globalization success story. The article examines the constant (re)creation of Irish identity and its complex (re)constitution in the era of globalization. It concludes that if an Ireland did not already exist, globalization theory would have to invent it.

G. Honor Fagan is a lecturer in sociology at the National University of Ireland, Maynooth. Her doctorate was awarded from Miami University, Oxford, Ohio, in 1991. Her current research interests include cultural politics, globalization and culture, civil society, and conflict resolution. She has done field research on early school leavers in Dublin for her book Cultural Politics and Irish Early School Leavers: Constructing Political Identities (1995) and on women in South African townships. She is currently living in Ireland and researching for a book titled Globalization and Culture: Repositioning Politics. 
T $\mathrm{N}$ spite of the criticisms accruing from second-generation globalization studies, the term "globalization" is still surviving as a description of the widening, deepening, and speeding up of global interconnectedness and its impact on social change and social processes on a world scale. Rather than dying off, it appears that the term is becoming increasingly popular with leading politicians now using it as a matter of course to describe the era we live in. Any event that appears on the world scene, for example, the events of 11 September, is now interpreted through the lens of globalization.

\section{INTRODUCTION}

At the level of the academy, globalization studies originally heralded the globalization of communications, capital, and culture almost in that order, and the argument was made that these globalization forces were in effect decomposing the nationstate and the distinctiveness of individual societies. This argument was followed immediately by critiques of the notion of an all-encompassing globalization process, and the work in this mode emphasized uneven, complex, and contingent aspects of globalization. This article seeks to position itself outside either of these established approaches to the study of globalization. Where, in general, the trend has been to show how global processes affect the production of single events or social change at the local or national level, I propose to reverse the trend by approaching an explanation of the global with specific reference to the national or local. Basically, I wish to ask the question, What can a study of Ireland do for understanding the phenomenon called globalization? rather than, How can globalization explain modern Ireland? In looking at the specificity of Irish international and national dynamics and the linkages between cultural and economic processes at play in developing or imagining Ireland, we can see tendencies and countertendencies toward globalizing dynamics.

This special issue looks at globalization and democracy, and this article attempts to look at the link between the two by emphasizing the articulation of the cultural and the economic at one and the same time in the production of Ireland in a global era. In short, the argument is that if we are to understand Ireland as a democratic nation, which has produced itself in its current form within and around the dynamics of the global forces of capitalism, then we need to examine the phenomenon of Ireland through an analytical framework of cultural political economy. This should throw light on globalization tendencies and countertendencies from a specific location and, likewise, show how culture implicates itself daily in the democratic processes that have produced Ireland.

The most common reading of Ireland and its current state of development is as a country that has done well in the era of globalization much as it had earlier done badly in the era of imperialism. Has there really been such a turnaround? What dynamics does this uncover that the emerging area of global studies needs to take on board? This article moves toward 
an answer in three parts: it examines first, the problematic placing of Ireland in the world; second, its constant (re)invention from a cultural political economy approach; and finally, its moving parts on the global scenes-its exiles and diasporas. I hope to contribute an Irish perspective that avoids the difficulties associated with taking either a nationalist or postnationalist approach.

\section{PLACING}

We can usually, fairly unproblematically, place a given country in the global order in terms of its economic, political, or strategic importance. Yet with Ireland, there is little agreement. Recently, a historian of the Americas, James Dunkerley (2000), sought to place Ireland "across the Atlantic" as it were. Dunkerley follows the tradition of "Atlanticism" (of Gilroy 1993) but is skeptical of "globalism." However, he argued for "the idea that Ireland is really an American country located in the wrong continent" (p. xxii). It was the Great Famine of the midnineteenth century and subsequent mass migrations that, supposedly, converted Ireland from an Atlantic country to an American one. This shift in cultural geography was sustained, according to Dunkerley, by a "superabundance of myth" (p. 37) but also validated by the one million Irish people who became U.S. citizens in the second half of the nineteenth century. From this perspective, it is easy to leap to another end of the century and in an economistic reading place Ireland as an outpost of the Silicon Valley. O'Hearn (1998) argued that U.S. computer and pharmaceutical companies set the tone for the "Celtic Tiger" that transformed the economic, social, and cultural makeup of the country. Whether the economic growth of the Celtic Tiger set the scene for the cultural makeup of Ireland or the cultural makeup set the scene for the economic growth, we have here an argument that Ireland can be historically and economically placed as an American country or outpost. Recent Irish political and social reaction to the terrorist threat to the United States, coming from conservative and radical politicians alike, seems to confirm the view that Irish leaders and the vast majority of its people wish Ireland to be seen as an island extension of the United States.

However, the American perspective seems to ignore the facts of British colonial rule in Ireland and the prevalence of a neocolonial pattern of development in the years since independence, itself of course geographically incomplete. Not so long ago, the question, "Is Ireland a Third World Country?" (Caherty et al. 1992) could elicit a mainly positive, albeit qualified, response. The colonial legacy is seen as enduring, and all attempts to revise Irish history beyond the nationalist myths are rejected out of hand. For Robbie McVeigh (1998), this move to "decolonise" (or "postcolonise") Irish history is "factually incorrect and intellectually dishonest," and we are enjoined "to address the colonial legacy directly in order to transcend its negative and corrupting consequences"(p. 31). The latter may be simply a truism, but it does point to a blind spot of the new 
postcolonial proglobalization perspectives. Perhaps our colonial legacy has indeed left the Irish leadership and the Irish psyche prone to adopt a subordinate attachment to imperialistic powers. Alternatively, it could have left us with a national consciousness that sees the need to struggle against imperial, or external, forces. A cultural reading would suggest that both might well be present at one and the same time. However, to return to the question of placing Ireland, at the economic level, we are certainly not simply a Third World (itself an anachronism) country. The Republic of Ireland is today one of the top performers in the European Union-the once poor and underdeveloped Western periphery gave way to a thriving economy and cultural revival in the nineties, albeit with all the inequalities and problematic long-term prospects all thriving economies have. However, in terms of the debate as to whether Ireland is a First World country of an American variety or a Third World country, rather than adjudicating between these admittedly rather starkly painted alternatives, I would like to use the debate as a marker for the analysis that follows.

First, though, I wish to argue for a slightly different approach to global studies than the one that dominates in the literature. It would seem that from Malcolm Waters $(1995,2001)$ onward, global studies has been parcelled out into discrete economic, political, social, and cultural domains or levels. While mindful that this may simply be a research or presentation strategy, I would be wary of going back to the old Marxist topographical analogy of levels. Society is simply not a building with a structure and a superstructure, or roof. This type of structural determinism has long since received a decent burial, and we would not really benefit from its resurrection within new global studies. The latter are at their best when they analyze processes and flows, not bound by any determinisms and self-consciously eschewing disciplinary boundaries. If the global studies approach is to become a new paradigm in the fullest sense of the word, it will need to shake off the last vestiges of disciplinary ownership. In terms of economics, there are signs that Ireland is a satellite of the United States, given its dependency on U.S.-based companies. In terms of politics, there are indications of the same, as Irish leaders rush to support the United States in its current difficulties. Likewise, cultural considerations feed into both economics and politics and have to be taken into account in placing Ireland. Hence, my suggestion to merge the political economy and cultural studies approaches.

It would be possible to start off with the recent call by Ngai-Ling Sim (2000) to create a "cultural political economy," which was at once sensitive to cultural or discursive dynamics and the role of economic and political factors. Nigel Thrift (2000) has also referred suggestively to the "cultural circuits of capital." Thinking about culture in Ireland (the Irish pub, Irish film, U2, Riverdance) and the new capitalism (software companies, the e-economy) has made me even more conscious of the need to 
build an integrated cultural political economy. The cultural element is clearly part and parcel of the Celtic Tiger, and the economic element certainly has a strong cultural component. From the critique of political economy (not its existing disciplinary forms) and from a reflexive cultural studies (not an unthinking application), we may derive a critical optic that is adequate for the study of the complex reality we call Ireland today. All I would add is the need for a historical approach, only sketched here given constraints of length, which is necessary to make any sense of the current situation. This is, of course, a contested historical terrain, and my rendering is not the only one possible.

\section{INVENTING}

Cultural critic Declan Kiberd (1995) once wrote that "if Ireland had never existed, the English would have invented it" (p. 9). One could add, conversely, that because England existed, Ireland was forced to invent itself, much as what the West knows as the Orient and Islam are inseparable from Western discourses. It is common now to understand that nationalism is indeed, in Hobsbawn's words, an "invented tradition" (Hobsbawn and Ranger 1983) or an "imagined community" (Anderson 1983). However, it would seem that in the era of globalization, this approach has great validity for Ireland in particular. What passes for Irish culture today-the musical dance show Riverdance, the supergroup U2, or the ubiquitous global Irish pub-does not spring from the eternal wells of the Irish soul. Rather these phenomena are, to a large extent, manufactured by the global cultural industry. They reflect fully all of the hybridity, syncretism, and even arguably the postmodernism typical of the cultural political economy of globalization. If globalization can be said to have produced a "world show case of cultures" (Featherstone 1995, 13), then on this stage, Ireland has achieved a paradigmatic position. Ireland today, or at least Dublin, is witnessing a cultureled process of regeneration and insertion into globalization in terms more favorable than could be expected from its economic weight. In fact, the two may well be linked -it is perhaps because of Ireland's economic lightness that it may have gone into overdrive in terms of its cultural production.

Historically, Ireland gained its partial independence from Britain in 1921. It was not until the Wall Street crash of 1929 and the Great Depression of the 1930s that a consistent path of inward-oriented growth began. While De Valera's notions might today smack of right-wing romantic isolationism, his industrialization policies did lay the basis for a more independent development strategy in Ireland. This process of conservative modernization can be compared to the "passive revolution" Antonio Gramsci (1971) analyzed in Italy: a case of "molecular changes which in fact progressively modify the pre-existing composition of forces and hence become the matrix of new change" (p. 109). That new process of change occurred in the late $1950 \mathrm{~s}$, as protectionism gave way to free trade 
and inward-oriented growth turned into outward-oriented growth. As T. K. Whitaker (1973), the architect of the post-1958 turn toward foreign loans and investments, put it at the time, "there is really no choice for a country wishing to keep pace materially with the rest of Europe" (p. 415). So, Ireland joined the European Economic Community in 1973, and the removal of protectionism proceeded at full pace.

When Ireland "joined" Europe in 1973 , it was very much as a poor relation and major beneficiary of all the structural funds made available for less developed regions. It seemed that Ireland was exchanging selfreliance for dependency in a willful shift away from the independence movement ethos. As Denis O'Hearn (1998) put it, "a country which had virtually clothed and shod itself in 1960 imported more than 71 per cent of its clothing in 1980" (pp.41-2). This shift away from indigenous industry toward transnational investment operated across the board. It coincided with a period in which U.S. transnational corporations were seeking profitable, high-tech locations, particularly ones that would offer them access to the lucrative European market. The outward-oriented growth orientations led to mass unemployment as national industries collapsed, but by the 1990 s, a new era of prosperity seemed to begin. Officially, the boom began in 1994, when in an obscure European investment assessment bulletin, the U.S. investment bank Morgan Stanley asked, perhaps tongue in cheek, whether there was a new Celtic Tiger about to join the family of east Asian tiger economies.

So the Celtic Tiger (the myth feeding the real economic advances) emerged just when globalization was beginning to make itself felt in earnest. This does not mean that globalization produced the Celtic Tiger, whose origins lay, as we saw in the bare outline, in a series of economic transformations going back to the 1920s. And while the Irish boom may be real enough, it has its limits: growth rates are half those experienced in east Asia during the growth phase, and its sustainability is seriously in question given the limited base of the growth sector. Dependency on the whims and market susceptibility of the transnational sector (essentially the computing and pharmaceutical sectors) is even greater than in the 1970s insofar as in the mid-1990s, this sector accounted for three-quarters of value added in manufacturing. A handful of computer companies, such as the giant processor manufacturer Intel, literally hold the key to sustained growth rates in Ireland. As the United States now moves into a slowdown if not a full-blown recession, the Celtic Tiger is beginning to look distinctly more fragile than it did a couple of years ago. Indeed, by late 2001, the Irish growth rate was officially described as flat.

Going back to Ireland as an American country and Ireland as a Third World country, what can we now say? Ireland does seem to be very much an American state, given its reliance on U.S. investments and its unthinking support for U.S. militarism abroad. Yet Ireland is very much still a Third 
World country in terms of its conditions of structural dependency. Ireland is perhaps more accurately described in terms of hybridity though, meaning mixed temporalities and a process of uneven development. This cutting-edge technology coexists with traditional social relations to a large extent. Luke Gibbons (1988) wrote a while back that "the IDA [Irish Development Authority, which helped bring in foreign investment] image of Ireland as the silicon valley of Europe may not be so far removed after all from the valley of the squinting windows" (p. 218), the latter an image of traditional rural Ireland. This image of uneven but combined development may serve as a useful and evocative backdrop for our analysis of the cultural political economy of contemporary Ireland.

Observers of the contemporary cultural scene in Ireland are impressed by its dynamism. Conservative politician Gemma Hussey (1995) in her book Ireland Today referred to a "new exuberance of selfexpression which the country has never seen before" and noted the "new Irish appetite for expression of its own identity" (pp. 470-71). We get a picture of a pristine and whole national identity proudly reasserting itself. Insularity is left behind as Ireland enters the world scene but remains in touch with its traditions. Hussey remarked how "traditional music has been revived in its many forms, and enthrals tourists as much as Irish people, who are themselves, amazed by its richness" (p. 484). From the touching tones of the travelogue, we receive an image of tradition largely uncontaminated by unpleasant associations with a colonial past or a fierce anti-imperialist struggle. Faced with the "inexorable weakening of the Irish language" ( $p$. 471), which Hussey seemed to see as the main repository of tradition, Ireland has been able to avoid "the pressure of Anglo-American media" ( $p$. 471) and construct for itself the eminently valuable commodity known as contemporary Irish culture.

From the Left of the political spectrum, we get a not dissimilar reading of Irish cultural political economy. Thus, Denis O'Hearn (1998) in his book Inside the Celtic Tiger referred to "Ireland's cultural revival throughout the Western world [which] was evidenced in the popularity of the musical Riverdance" (p. 117) and also made an explicit link between "an apparently vibrant economy and a confident culture" (p. 57). As with Hussey (1995), the parameters of the nation-state are taken for granted, and one could be forgiven for thinking that globalization was not part of the picture at all. Where the Left analysis differs from the conservative one is only in causation, because its economism leads it to more or less read off the cultural transformations from the economic ones. Yet ultimately, we get no explanation as to why Ireland has been part of "a Pan-Celtic Revival in the years leading up to the millennium" and has lived "what amounts to little less than another Cultural Renaissance" (Smyth 1997, 175), as a radical cultural critic put it. If we are not to fall back on mystical notions of national culture, we must necessarily begin with the cultural political 
economy of globalization in seeking an explanation.

I find it helpful to start my alternative reading with a travel story of my own. If you were to visit Ireland, you might wish to travel with "Ireland's cheap fares airline," Ryanair. If you made a telephone booking, you would be politely put on hold and left listening to the rousing theme music from Riverdance, as much flamenco and Broadway as traditional Irish music. From this postmodern pastiche or melange, your thoughts might turn to the company itself. Ryanair is typical of the new hollowed-out company, whose brash manager Michael O'Leary is actually the company and epitomizes the new confident Irish entrepreneurial classes. It contrasts with the bureaucratic, more formal national carrier Aer Lingus that still lingers in the statist era and claims massive compensation for its alleged losses following 11 September. But you travel Ryanair and arrive in Dublin along with thousands of European weekend tourists keen to sample the delights of the fashionable Temple bar area. As you get to passport control, there is a billboard with a leprechaun (a traditional icon of Irish folklore) and a caption that reads, "If you think this is an icon of traditional Ireland you are away with the fairies." A small symbol in the corner of the billboard indicates this is an advertisement for ICON, the marketing company for the traditional global Irish cream liqueur Bailey's. Can we really talk about Irish traditions anymore?

It seems clear to me that globalization has radically redefined what we know as tradition. But then tradition was always invented. It was invented in the Ireland of the $1920 \mathrm{~s}$, the $1960 \mathrm{~s}$, and the 1990s. In the $1920 \mathrm{~s}$, as Declan Kiberd (1995) put it, the country engaged in "the reconstruction of a national identity, beginning from the first principles all over again" (p. 286). De Valera and the founders of the national Irish state were in the business of constructing a modernity based on tradition. To refer to tradition or cultural authenticity today makes little sense when we realize how pragmatic an affair the construction of a national identity is. In the $1960 \mathrm{~s}$, there was a reconstruction based on transnational values, first American and later European. Then in the 1990s, there was another reconstruction of Irish identity within global parameters. The dance of Riverdance, the music of the Chieftans, and the new Irish film cannot be understood as national cultural forms. They may be partly constituted locally, but it is with reference to a global cultural market: they are local cultural keys turning global locks.

I can only conclude by rejecting any essentialist notion of Irishness that is fixed from time immemorial. Neither Irish culture nor Irish identity can be seen as self-contained, immutable, or closed. A new state of flux, typical of postcolonialism and globalization, opens up a new era of more fluid and uncertain construction of cultural identity. This is also manifest at the political levelwhere the future of the island is, as always, uncertain. There is hardly a comfortable situation of cultural diversity being constructed where gender, ethnicity, and religious 
conflicts become safely defused. Ireland's culture is currently showing a more threatening side. Current racism around the issue of immigration and refugees highlights some of the more worrying sides of the uncertainty we now face. This is hardly the positive scenario of Gemma Hussey (1995), for whom insularity has been replaced by "the confidence of an outward-looking young generation" ( $p$. 484).

\section{MOVING}

Cultural critic Terry Eagleton (1997) once wrote that while on one hand, Ireland signifies "roots, belonging, tradition," it also spells at the same time "exile, diffusion, globality, diaspora" (p. 11). We could posit that Ireland was always/already part of the story of globalization, which would mean pushing back its conventional temporal origins. Being Irish was always associated with movement, even while being at home. Irish migration and the substantial Irish diaspora in different parts of the globe meant that Irishness was in a very real sense a globalized identity. That was the case at the last turn of century, but now, in the era of globalization, migration is not so prevalent or economically necessary. It is perhaps ironic, then, that today Irishness is finding confident homegrown roots and that home has a certain stability to it. Irish presidents recently (Robinson and McAleese) have foregrounded the wish to bring the diaspora home, culturally and politically, if not physically. The confidence of Irishness on the island of Ireland today has even led to intense hostility to today's migrants created by globalization-the asylum seekers and refugees.

Movement in the nineteenth century meant dislocation, rupture, and trauma in Ireland. It was associated with the famine, the British landlord, and unemployment. Emigration was, indeed, the national trauma. Today, movement means travel, working abroad, or coming home. The Irish media portray its citizens as the "Young Europeans": computer literate, confident citizens of the world. Migration, then, cannot have a simple meaning as a symptom of globalization. It can signify expulsion or, as in Ireland today, success. The diaspora was once an integral element of Irish identity. Today there is a move to bring it home, but home is not what it used to be. The Ireland of today has seen the full effect of deterritorialization of culture. Observer Fintan O'Toole (2000) noted that at once "US culture is itself in part an Irish invention" and that "Irish culture is inconceivable without America" (p. 12). Fluidity and hybridity have always been part of the Irish condition, but today, this occurs under the inescapable aegis of the United States, not some fuzzy, indistinct era of globalization.

Ireland was always part of broader flows of people and ideas; it was always globalized, and it was always a floating signifier. National tradition was located as much in the diaspora as at home. And home today, as the accelerated movement of globalization takes effect, is reinstated in the global Irish family our politicians call the diaspora. National identity is translated and appropriated by the 
new global culture. When U2 refer to the famine, they do so in a way that makes it part of the new global history in the making. What might make an interesting analogy to extend this analysis would be John Urry's (2000) concept of sites of "pure mobility" (p. 63). For Urry, society is today replaced by mobility, with such icons as the airport becoming truly "non-places." What if Ireland were to be conceived as a place of pure mobility, dominated by movement and fluidity? Though only an analogy, and one that cannot be stretched too far, it may help us understand why Ireland is significant for an understanding of globalization, too often read from the perspective of stable, settled, and dominant world powers.

\section{CONCLUSION}

It would seem that the cultural political economy of Ireland might take us beyond the stark American and Third World options for placing Ireland. We cannot retreat to an essentialist notion of Irishness existing since time immemorial. The cultural political economy of Ireland has never been self-contained, immutable, or closed. The era of globalization, coinciding in Ireland with that of a postcolonialism, which put the British shadow firmly behind, has created the new context for Irish development. And yet Ireland was always part of a world of flows, never static, never fixed. The elements of uncertainty and undecidability, which many see as pertaining to globalization and/or postmodernity, have always been Ireland's lot. We cannot, in Ireland, produce "a finished image of finished reality" (Smyth 1997, 67) because it has always been in flux. To engage with such a society, a novelist or short story writer is necessarily "constrained to open meaning up rather than close it down," (Smyth 1997, 67) as one cultural critic put it. The social and political scientist can hardly do otherwise.

A recent International Studies Association conference contained presentations that referred to globalization and the "preservation of local identity" in Ireland (White 2001). Ireland is seen as one of those states that have "taken advantage of the new opportunities afforded by contemporary globalization" (White 2001), and the conclusion is that "the Irish have culturally escaped from a parochial sense of nationalism and become a proud member of the international community" (White 2001). While capturing something of what is happening in Ireland today, I think it is clear, in the light of my analysis above, why this approach is insufficient. It seems to buy in totally to the ideology of globalization: if we take advantage of it, we can escape parochial nationalism. It was thus patronizing politics I sought to contest in declaring at the start that this article was neither nationalist nor postnationalist. Many social groups in Ireland, many women especially, have always contested the smug conservative self-serving myths of Irish nationalism. Postnationalist accounts that imply that we have moved into a sea of tranquillity where all conflict will be peacefully resolved in Brussels or Washington are also problematic. Ultimately, 
what the Irish case study shows us is that the world is a more complex place than a simple binary opposition of "Jihad versus McWorld" (Barber 1995).

\section{References}

Anderson, B. 1983. Imagined communities. London: Verso.

Barber, B. 1995. Jihad vs McWorld. New York: Ballantine.

Caherty, T., A. Storey, M. Gavin, M. Molloy, and C. Ruane. 1992. Is Ireland a Third World Country? Belfast, Ireland: Beyond the Pale.

Dunkerley, J. 2000. Americana. London: Verso.

Eagleton, T. 1997. The ideology of Irish studies. Bullan 1 (1): 5-14.

Featherstone, M. 1995. Undoing culture: Globalization, postmodernism and identity. London: Sage.

Gibbons, L. 1988. Coming out of hibernation? The myth of modernity in Irish culture. In Across the frontiers: Ireland in the 1990's, edited by R. Kearney. Dublin, Ireland: Wolfhound Press.

Gilroy, P. 1993. The black Atlantic. London: Verso.

Gramsci, A. 1971. Selections from the prison notebooks. London: Lawrence and Wishart.

Hobsbawn, E., and T. Ranger, eds. 1983. The invention of tradition. Cambridge, UK: Cambridge University Press.

Hussey, G. 1995. Ireland today: Anatomy of a changing state. London: Penguin.

Kiberd, D. 1995. Inventing Ireland: The literature of the modern nation. London: Jonathan Cape.
McVeigh, R. 1998. The British/Irish "peace process" and the colonial legacy. In Dis/Agreeing Ireland, edited by J. Anderson and J. Goodman. London: Pluto.

O'Hearn, D. 1998. Inside the Celtic Tiger: the Irish economy and the Asian model. London: Pluto.

O'Toole, F. 2000. The ex-isle of Erin: Images of a global Ireland. Dublin, Ireland: New Island Books.

Smyth, G. 1997. The novel and the nation: Studies in the new Irish fiction. London: Pluto.

Sim, N.-L. 2000. Globalization and its "other(s)": Three "new kinds of Orientalism" and political economy of transborder identity. In Demystifying globalization, edited by C. Hay and D. Marsh. New York: Palgrave.

Thrift, N. 2000. State sovereignty, globalization and the rise of soft capitalism. In Demystifying globalization, edited by C. Hay and D. Marsh. New York: Palgrave.

Urry, J. 2000. Sociology without society. London: Sage.

Waters, M. 1995. Globalization. London: Routledge.

. 2001. Globalization. 2d ed. London: Routledge.

Whitaker, T. K. 1973. From protection to free trade-The Irish Case. Administration (winter).

White, T. 2001. Globalization and the preservation of local identity: The case of Ireland. Paper presented at the International Studies Association Convention, Hong Kong. 
ANNALS, AAPSS, 581, May 2002

\title{
Democracy and the Transnational Capitalist Class
}

\author{
By LESLIE SKLAIR
}

\begin{abstract}
While globalization means many different things to many different people, there is growing consensus that capitalist globalization is its most powerful contemporary form. This article argues that capitalist globalization, and thus effective power in the global system, is increasingly in the hands of a transnational capitalist class (TCC) comprising four fractions: those who own and control the major corporations and their local affiliates, globalizing bureaucrats and politicians, globalizing professionals, and consumerist elites. The TCC engages in a variety of activities that take place at all levels, including community, urban, national, and global politics, and involve many different groups of actors. Two sets of questions are addressed: (1) What forms do these activities take? and (2) Do they enhance or undermine democracy? The role of the TCC is analyzed through brief case studies on Codex Alimentarius and the global tobacco industry.
\end{abstract}

Leslie Sklair teaches and directs the Ph.D. program in the sociology department at the London School of Economics and Political Science. He has researched transnational corporations all over the world and is author of The Transnational Capitalist Class (2001), Assembling for Development: The Maquila Industry in Mexico and the US (second edition 1993), and Sociology of the Global System (1991; second edition 1995), which has been translated into Japanese, Portuguese, Persian, Chinese, and Spanish (forthcoming). A new version of this book, titled Globalization: Capitalism and Its Alternatives, will be published by Oxford University Press in 2002.

NOTE: Parts of this article were previously published in International Political Science Review, 23 (2): 159-174 (April 2002). 